\title{
NIH confirms violation of recombinant DNA research guidelines
}

AN internal inquiry conducted by the National Institutes of Health has confirmed allegations first made public last December that a research worker at Harvard Medical School carried out experiments involving recombinant DNA techniques in violation of guidelines laid down by the NIH.

The inquiry has revealed that $\mathrm{Dr}$ Charles A. Thomas, then professor of biological chemistry and now with the Scripps Clinic and Research Foundation at La Jolla, California, carried out research using such techniques without filing a 'memorandum of understanding and agreement' as required by the NIH guidelines published in 1976.

It also found that although the Harvard Medical School Committee on Recombinant DNA Molecules had, for a number of reasons, not approved an MUA submitted by Dr Thomas in November 1976, he had continued to do recombinant DNA research up to December 1977 without the committee knowing.

The NIH inquiry was carried out by Mr James Schriver, director of the institutes' division of management and review, at the request of NIH director Dr Donald Fredrickson. The allegations that Dr Thomas had failed to file an MUA were made by an environmentalist group following information received through a 'freedom of information' petition.

In his report $\mathrm{Mr}$ Schriver says that although no mention was made by Dr Thomas in various grant applications to the NIH that experiments involving DNA molecules were to be performed, a grant from NIH was cited as supporting a paper published in May 1976 which described DNA cloning.

$\mathrm{Mr}$ Schriver reports that at a meeting last December, Dr Thomas stated that he had been performing recombinant DNA experiments continuously at the P2 level. "He made this statement even though virtually all the support he had been receiving for his research consisted of his NIH grants which did not contemplate experiments of this type," Mr Schriver says.

The report also describes lengthy negotiations which took place between Dr Thomas and the medical school's Recombinant DNA Executive Committee about whether Dr Thomas' research facilities met the containment requirements laid down in the NIH guidelines for the type of research that he was carrying out. In particular, Dr Thomas had initially argued that his laboratory met the requirements for P3 containment levels: the resultant dispute with the Harvard Committee contributed to the delays in filing a MUA.

Harvard Medical School recently released its own report on the affair, prepared by an ad hoc university faculty committee. It says that the committee had been convinced that the research directed by $\mathrm{Dr}$ Thomas had been carried out safely with no threat to the health of those involved.

It says that the failure to file a MUA with the NIH was the combined result of misunderstandings and differences of opinion within Harvard about the requirements embodied in the NIH guidelines, failures in communication between Dr Thomas, the Recombinant DNA Executive Committee and the $\mathrm{NIH}$, and administrative lapses in the latter two institutions. Guilt did not rest with one person alone, it added.

Dr Fredrickson said last week that he had asked the NIH Executive Recombinant DNA Committee to analyse both reports and make recommendations about what action would be taken.

David Dickson

\section{WMO planning world climate study}

A MEETING hosted earlier this year by the international Institute of Applied Systems Analysis (IIASA) on behalf of the World Meteorological Organisation (WMO) set the seal on preparations for the World Climate Conference, to be held in Geneva in February nexî year. The conference will be an essential preliminary to the World Climate Programme, a massive project in which virtually ail the specialised agencies of the UN system will be involved in one way or another. with WMO as the "lead agency".

We really know remarkably little about climate. The big, WMOsponsored projects such as the 'global atmosphere rescarch programme' (GARP) and the 'world weather watch' are now beginning to show some results, and these will be among the inputs to next year's conference, together with results from various inter-agency projects in which WMO is also involved. But the main objective will be to assess our present knowledge of climate, and to plan a long term, global research programme. Such a programme, WMO points out, must be based on accurate. readily available data, including past records of whatever sort; forecasting. in particular for longer ranges than is at present possible; and hence, studies of the impact of climate on human activities, and the feed-back from those activities, such as the possible effects on the atmosphere of increasing amounts of $\mathrm{CO}_{2}$.

The recent meeting was a preliminary gathering of 20 to 25 meteorologists and others who were invited to contribute major papers to the conference itself. The idea was to avoid duplication and unnecessary overlapping at the main meeting. Each of the specialised agencies involved --. UNESCO, FAO, ICAO for example-contributed papers in their own special fields, while IIASA was concerned in

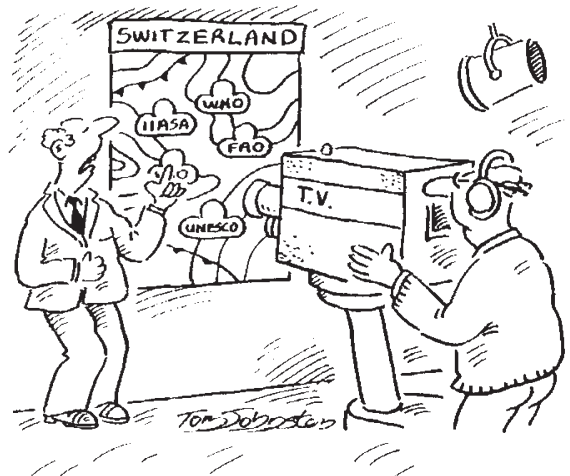

"There will be heavy showers of acronyms in the Geneva area!" the production and operation of computer models, now being increasingly used in climate studies. The main conference, which has a multi-agency planning committee, will last two weeks. In sharp contrast to such recent UN gatherings as those concerned with water and desertification, it will be a strictly scientific affair, with probably not much over 100 participants. After consideration by the next World Meteorological Congress, due in the Spring of 1979, the conclusions of the conference should form a basis for planning the World Climate Programme itself. This in turn will be the subject of a major planning and administrative conference some months later.

The quiet way in which WMO is going about this whole project is typical of this small, but perhaps most efficient of UN specialised agencies. In particular, the insistence that the recent meeting was scientific should have avoided the previous publicity and subsequent disillusion associated with too many large conferences within the UN system. The conclusions drawn and activities planned should form a part of WMO's own submission to the next of these events. the UN Conference on Science and Technology for Development, to be held in Vienna next year.

Peter Collins 